\title{
Challenging building blocks: Cosmology, matter, religion, sexuality and language
}

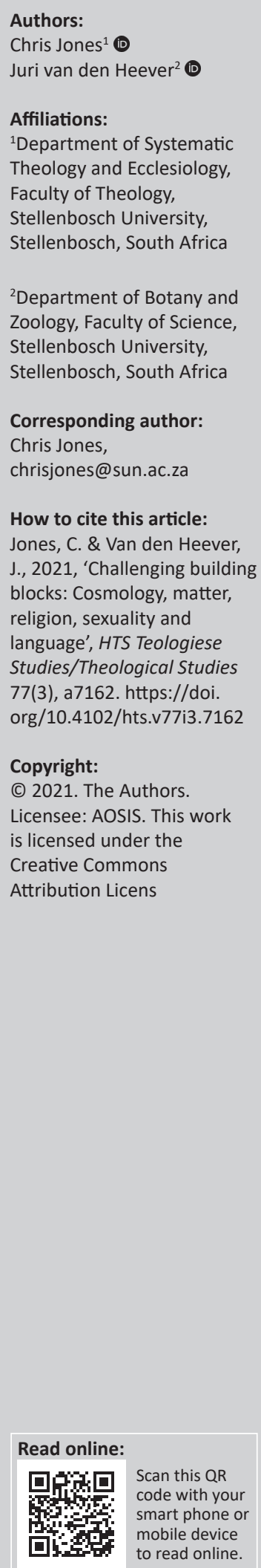

This is the second series in our special collection on challenging building blocks of our past, present, and future. This series consists of five articles. (1) 'The building blocks of the universe' is written by cosmologist Anslyn John. In this contribution, he not only discusses the building blocks of the universe, but also highlights certain unsolved problems and proposes some solutions (John 2021). (2) In their article: 'The building blocks of matter' physicists, Delia Haynes and Mags Blackie present 'the historical development of key ideas' in their understanding of matter, 'along with some of the important ideas in understanding how matter behaves' (2021:1). They also consider 'the implications of the meaning and utilisation of this knowledge' (Haynes \& Blackie 2021:1). (3) Old Testament scholar Sakkie Spangenberg discusses the 'Building blocks of religion: Music, dance, songs and stories' and argues that although the 'Bauplan of religions change when societies change, the building blocks remain the same' (2021:1). He identifies 'music, dance, songs and stories ... as important building blocks of religions', and makes the point that it is 'especially stories that contribute to the formation of a new religion and to the coherence of the new society' (p. 1). (4) The fourth article by theologian Chris Jones and Karoo palaeontologist Juri van den Heever focusses on the 'Building blocks of sexuality'. 'Differences in brain development in the womb, specific genetic factors influencing sex-reversal phenotypes and how they give rise to different sexes and sexual orientations' (p. 1) are discussed. It reviews gender identity and expression, and a practical road map for religious denominations to responsibly engage with human sexuality, especially same-sex lifestyles within their spheres of influence, is presented (Jones \& Van den Heever 2021). In the last article of this specific series, 'Building blocks of language', Chris Jones and Juri van den Heever unpack the evolutionary emergence of language from an essentially empirical point of view. Specific perspectives on the historical origin and modern practice of human language have been chosen and are discussed and reviewed (2021). These articles are not only based on historical thought but also on contemporary research. It fits well with the intersectional and interdisciplinary nature of this collection and journal. International scholars, peers, and researchers with an interest in these topics, are the target audience of this collection.

All the articles are based on original research and no part of this collection was plagiarised from another publication or published elsewhere.

\section{References}

Haynes, D.A. \& Blackie, M.A.L., 2021, 'The building blocks of matter', HTS Teologiese Studies/Theological Studies 77(3), a6809. https://doi.org/10.4102/hts.v77i3.6809

John, A.J., 2021, 'The building blocks of the universe', HTS Teologiese Studies/Theological Studies 77(3), a6831. https://doi.org/10.4102/ hts.v77i3.6831

Jones, C. \& Van den Heever, J., 2021, 'Building blocks of sexuality', HTS Teologiese Studies/Theological Studies 77(3), a6569. https://doi. org/10.4102/hts.v77i3.6569

Spangenberg, I.J., 2021, 'Building blocks of religion: Music, dance, songs and stories', HTS Teologiese Studies/Theological Studies 77(3), a6784. https://doi.org/10.4102/hts.v77i3.6784 